\title{
KAJIAN EVALUASI MUTU SUNGAI NELAS DENGAN METODE STORET DAN INDEKS PENCEMARAN
}

\author{
Operi Arnop $^{1)}$, Budiyanto ${ }^{2)}$, Rustama ${ }^{3)}$ \\ ${ }^{1)}$ Program Pascasarjana Pengelolaan Sumber Daya Alam dan Lingkungan, Fakultas \\ Pertanian, Universitas Bengkulu \\ ${ }^{1)}$ Dinas Lingkungan Hidup dan Kehutanan Provinsi Bengkulu \\ ${ }^{2)}$ Jurusan Teknologi Industri Fakultas Pertanian Universitas Bengkulu \\ ${ }^{3)}$ Jurusan Peternakan Fakultas Pertanian Universitas Bengkulu
}

\begin{abstract}
ABSTRAK
Ratu Air Sungai Nelas yang diatur didalam Peraturan Daerah Provinsi Bengkulu Nomor 6 Tahun 2005 ditetapkan sebagai air Sungai Kelas I (Satu). Setelah beberapa tahun sejak ditetapkannya Perda tersebut diperkirakan kualitas air Sungai Nelas telah mengalami penurunan status mutu. Penelitian ini bertujuan untuk menentukan status mutu air Sungai Nelas saat ini, menentukan kelayakan air Sungai Nelas sebagai bahan baku air PDAM, mengevaluasi kelayakan status mutu air Sungai Nelas sesuai Perda Nomor 6 tahun 2005, dan mengevaluasi status mutu air Sungai Nelas dari tahun 2014 sampai tahun 2017. Dalam penelitian ini ditentukan 5 (Lima) titik sampling air Sungai Nelas dari hulu di Kabupaten Seluma sampai ke hilir di Kota Bengkulu. Pengambilan sampel dilakukan pada musim kemarau dan musim penghujan. Hasil pengukuran lapangan dianalisa dengan menggunakan Metode STORET dan Indeks Pencemaran (IP) untuk menentukan status mutu air Sungai Nelas. Hasil penelitian ini mengindikasikan bahwa air Sungai Nelas sudah mengalami penurunan status mutu. Status mutu air Sungai Nelas yang diatur didalam Perda Nomor 6 Tahun 2005 sudah tidak sesuai dengan kondisi senyatanya dilapangan.
\end{abstract}

Kata Kunci : status mutu, pencemar, kelas air, kualitas air, das nelas

\section{PENDAHULUAN}

Air merupakan komponen lingkungan hidup yang penting bagi kelangsungan hidup manusia dan makhluk hidup lainnya. Dalam Peraturan Pemerintah Nomor 82 Tahun 2001 tentang Pengelolaan Kualitas Air dan Pengendalian Pencemaran Air maka air merupakan salah satu sumber daya alam yang memiliki fungsi sangat penting bagi kehidupan manusia serta untuk memajukan kesejahteraan umum sehingga merupakan modal dasar dan faktor utama pembangunan. Dalam kehidupan sehari hari, peranan air selain sebagai bahan baku air minum juga digunakan untuk aktivitas manusia seperti pengairan, pertanian, kegiatan industri dan lain - lain. Maka sekarang ini air menjadi subjek yang perlu mendapat perhatian yang seksama dan cermat (Manik, 2016).

Di dalam suatu sistem Daerah Aliran Sungai (DAS), sungai yang berfungsi sebagai wadah pengaliran air selalu berada di posisi paling rendah dalam landskap bumi, sehingga kondisi sungai tidak dapat dipisahkan dari kondisi Daerah Aliran Sungai (PP 38 Tahun 2011). Kualitas air sungai dipengaruhi oleh kualitas pasokan air yang berasal dari daerah tangkapan sedangkan kualitas pasokan air dari daerah tangkapan berkaitan dengan aktivitas manusia yang ada di dalamnya (Wiwoho, 2005).

Pertambahan jumlah penduduk dan aktivitas di sepanjang daerah aliran sungai memberikan andil dalam perubahan 
kualitas sungai. Semakin banyak aktivitas di sepanjang daerah aliran sungai tersebut maka semakin besar pula potensi pencemaran yang mungkin terjadi. Pencemaran ini mengakibatkan menurunnya kualitas kesehatan masyarakat terutama masyarakat yang berada di sekitar daerah aliran sungai yang kesehariannya memanfaatkan sungai tersebut. Pencemaran tersebut juga mengakibatkan rusaknya ekosistem sungai, dimana biota - biota sungai yang semakin berkurang. Hal ini tentunya juga akan mempengaruhi perekonomian masyarakat daerah aliran sungai (Eko, 2015).

Perubahan kondisi kualitas air pada aliran sungai merupakan dampak dari buangan dari penggunaan lahan yang ada (Tafangenyasha dan Dzinomwa, 2005) Perubahan pola pemanfaatan lahan menjadi lahan pertanian, tegalan dan permukiman serta meningkatnya aktivitas industri akan memberikan dampak terhadap kondisi hidrologis dalam suatu Daerah Aliran Sungai. Selain itu, berbagai aktivitas manusia dalam memenuhi kebutuhan hidupnya yang berasal dari kegiatan industri, rumah tangga, dan pertanian akan menghasilkan limbah yang memberi sumbangan pada penurunan kualitas air sungai (Suriawiria, 2003).

Pencemaran lingkungan adalah masalah yang akan selalu dihadapi oleh sekumpulan masyarakat yang berada di suatu lingkungan tertentu. Pencemaran ini dapat berupa pencemaran udara, pencemaran air ataupun pencemaran tanah. Seiring dengan berkembangnya industri dan pembangunan yang cukup tinggi, khususnya di wilayah Kabupaten Seluma, tentu saja akan semakin meningkatkan beban pencemaran. Salah satunya adalah beban limbah cair atau air buangan yang dihasilkan, yang akan menambah pencemaran pada perairan yang merupakan salah satu media pembuangan dari limbah atau buangan tersebut (Anindya, 2006).

Seiring dengan meningkatnya jumlah penduduk berikut dengan kebutuhannya sehingga menyebabkan peningkatan kuantitas produksi. Untuk dapat memenuhi peningkatan kuantitas produksi, maka otomatis kebutuhan penggunaan sumber daya alam juga akan meningkat, yang pada akhirnya menimbulkan beban pada lingkungan hidup seperti turunnya daya dukung lingkungan. Sebagai contohnya turunnya daya dukung sungai dimana badan air ini sering digunakan sebagai media akhir pembuangan limbah dari segala kegiatan manusia. Dengan semakin bertambahnya jumlah kegiatan atau industri kecil serta berkembangnya hasil produksi di beberapa kegiatan atau industri di Kabupaten Seluma tentunya akan beresiko terhadap turunnya daya dukung sungai (Mundiatun, 2016).

Status mutu air adalah tingkat kondisi mutu air yang menunjukkan kondisi cemar atau kondisi baik pada suatu sumber air dalam waktu tertentu dengan membandingkan dengan baku mutu air yang ditetapkan. Dengan cara ini, kualitas suatu sumber air dapat dikelompokkan ke dalam kelas tertentu, sesuai dengan tingkat pencemarannya, apakah memenuhi standar sesuai peruntukannya, ataukah berada dalam kondisi tercemar dengan tingkat pencemaran tertentu, misalnya cemar ringan, sedang atau berat (Pardamean, 2015).

Status mutu air selama ini ditetapkan melalui dua metode yang dicantumkan dalam Keputusan Menteri Negara Lingkungan Hidup Nomor 115 Tahun 2003 tentang Pedoman Penentuan Status Mutu Air, yaitu metode STORET dan metode Indeks Pencemaran yang dikembangkan oleh Nemerow \& Sumitomo (Karliansyah, 2016).

\section{METODE PENELITIAN}

Penelitian dilakukan di Sungai Nelas, Kabupaten Seluma. Penelitian kualitas air dilakukan dengan membagi sungai menjadi 5 segmen dimulai dari hulu di Kecamatan Periukan hingga ke hilir 
Kelurahan Padang Serai Kecamatan Kampung Melayu Kota Bengkulu dengan 5 titik lokasi pengambilan sampel. Analisis laboratorium dilakukan di UPTD Laboratorium Dinas Lingkungan Hidup dan Kehutanan Provinsi Bengkulu terakreditasi KAN (Komite Akreditasi Nasional) LP-906-IDN, dan UPT Laboratorium Lingkungan Dinas Lingkungan Hidup Kota Bengkulu. Pengambilan sampel air sungai dilakukan pada musim kemarau dan musim penghujan tahun 2017.

Metode yang digunakan dalam pengambilan sampel uji Sungai Nelas adalah mengacu ke SNI 6989.57 : 2008 Metoda Pengambilan Contoh Air Permukaan. Titik pengambilan contoh air sungai ditentukan berdasarkan debit air sungai yang diatur dengan ketentuan sebagai berikut :

a. Sungai dengan debit kurang dari 5 $\mathrm{m}^{3} /$ detik, contoh diambil pada satu titik ditengah sungai pada kedalaman 0,5 kali kedalaman dari permukaan air.

b. Sungai dengan debit antara $5 \mathrm{~m}^{3} /$ detik - $150 \mathrm{~m}^{3} /$ detik, contoh diambil pada dua titik masing-masing pada jarak $1 / 3$ dan $2 / 3$ lebar sungai pada kedalaman 0,5 kali kedalaman dari permukaan air.

c. Sungai dengan debit lebih dari 150 $\mathrm{m}^{3} /$ detik, contoh diambil minimum pada enam titik masing-masing pada jarak 1/4, 1/2, dan 3/4 lebar sungai pada kedalaman 0,2 dan 0,8 kali kedalaman dari permukaan air (Anwar H, 2005).

Parameter kualitas air Sungai Nelas yang diperiksa meliputi parameter fisika (Suhu / temperatur, Salinitas, TDS, TSS, dan DHL). Parameter kimia ( $\mathrm{pH}, \mathrm{DO}, \mathrm{Fe}$, $\mathrm{Mn}, \mathrm{Cu}, \mathrm{BOD} 5, \mathrm{COD}, \mathrm{SO} 4$, Nitrit (NO2$\mathrm{N})$, dan Minyak Lemak. Parameter biologi (Coliform, dan Total Coli). Total 16 parameter yang dianalisa terkait kualitas air Sungai Nelas.
Untuk parameter sesaat dan akan langsung dianalisa di lapangan, seperti parameter $\mathrm{pH}$, temperature, TDS, TSS, DHL, DO, dan Salinitas. Untuk parameter uji laboratorium akan diambil sampel nya sesuai dengan tata cara pengambilan sampel sesuai dengan SNI 6989.57 : 2008 tentang Metoda Pengambilan Contoh Air Permukaan, dan segera dianalisa di UPTD Laboratorium Dinas Lingkungan Hidup dan Kehutanan Provinsi Bengkulu dan UPT Laboratorium Dinas Lingkungan Hidup Kota Bengkulu.

\section{Metode STORET}

Penentuan status mutu air dalam penelitian ini menggunakan metode STORET dan Indeks Pencemaran (IP) yang diatur dalam Keputusan Menteri Negara Lingkungan Hidup No. 115 tahun 2003 tentang Pedoman Penentuan Status Mutu Air. Secara prinsip metode STORET dan IP adalah membandingkan antara data kualitas air dengan kelas air yang disesuaikan dengan peruntukannya guna menentukan status mutu air. Cara untuk menentukan status mutu air pada metode STORET adalah dengan menggunakan sistem nilai dari "US-EPA (Environmental Protection Agency) dengan mengklasifikasikan mutu air dalam empat kelas. Sedangkan pada metode IP ditentukan dari resultan nilai maksimum dan nilai rata - rata rasio konsentrasi per parameter terhadap nilai baku mutunya. Parameter yang digunakan dalam penelitian ini adalah Suhu/Temperatur, TDS, TSS, DHL, pH, DO, Fe, Mn, Cu, BOD5, COD, SO4, Nitrit (NO2-N), Minyak Lemak, Salinitas, Coliform, dan Fecal Coli. Hasil analisa sampel akan digunakan untuk menentukan status mutu air dengan menggunakan metode STORET dan Indeks Pencemaran (IP). Berdasarkan Permen LH nomor 115 tahun 2003 tentang Penentuan Status Mutu Air, Metode STORET merupakan salah satu metode untuk menentukan status mutu air yang umum digunakan. Dengan metode 
STORET ini dapat diketahui parameter parameter yang telah memenuhi atau melampaui baku mutu air. Secara prinsip metode STORET adalah membandingkan antara data kualitas air dengan baku mutu air yang disesuaikan dengan peruntukannya guna menentukan status mutu air. Cara untuk menentukan status mutu air adalah dengan menggunakan sistem nilai dari "US - EPA (Environmental Protection agency)" dengan mengklasifikasikan mutu air dalam empat kelas, yaitu

(1) Kelas A : baik sekali, skor $=0$ ( memenuhi baku mutu)

(2) Kelas B : baik, skor = $-1 \mathrm{~s} / \mathrm{d}-10$ (cemar ringan)

(3) Kelas C : sedang, skor $=-11 \mathrm{~s} / \mathrm{d}-30$ (cemar sedang)

(4) Kelas D : buruk, skor $==-31$ (cemar berat)

\section{Metode Indeks Pencemaran (IP)}

Indeks Pencemaran (IP) digunakan untuk menentukan tingkat pencemaran relatif terhadap parameter kualitas air yang diizinkan. Pengelolaan kualitas air atas dasar Indeks Pencemaran (IP) ini dapat memberi masukan pada pengambil keputusan agar dapat menilai kualitas badan air untuk suatu peruntukan serta melakukan tindakan untuk memperbaiki kualitas jika terjadi penurunan kualitas akibat kehadiran senyawa Pencemaran. IP mencakup berbagai kelompok parameter kualitas yang independent dan bermakna (Rosalia, 2017). Kategori kelas Indeks Pencemaran (IP) adalah sebagai berikut :

1. $0 \leq \mathrm{IP} \leq 1=$ memenuhi baku mutu (baik) / good

2. $1 \leq \mathrm{IP} \leq 5=$ tercemar ringan / slightly polluted

3. $5 \leq \mathrm{IP} \leq 10=$ tercemar sedang / fairly polluted

4. IP $>10=$ tercemar berat / heavily polluted (Saraswati dkk, 2014).

Secara umum persamaan yang digunakan untuk menentukan Indeks Pencemaran adalah sebagai berikut :

$$
\mathrm{PIj}=\sqrt{\frac{\{C i / L i\}_{M}^{2}\{C i / L i\}_{R}^{2}}{2}}
$$

Keterangan :

$\mathrm{PIj}=$ indeks Pencemaran bagi peruntukan $\mathrm{j}, \mathrm{Ci}=$ konsentrasi parameter kualitas air $\mathrm{i}, \mathrm{Lij}=$ konsentrasi parameter kualitas air i yang tercantum dalam baku peruntukan air, $\mathrm{M}$ = maksimum, $\mathrm{R}=$ rata - rata, $\left(\mathrm{C}_{\mathrm{i}} / \mathrm{L}_{\mathrm{ij}}\right)_{\mathrm{R}}=$ indeks rata-rata, dan $\left(\mathrm{C}_{\mathrm{i}} / \mathrm{L}_{\mathrm{ij}}\right)_{\mathrm{M}}=$ indeks maksimum.

Perhitungan IP sesuai dengan pedoman yang ada pada Keputusan Menteri Negara Lingkungan Hidup No. 115 tahun 2003 dilakukan sesuai dengan prosedur berikut :

1. Menghitung harga $C$ untuk tiap parameter pada setiap lokasi pengambilan sampel dengan $\mathrm{Ci}$ adalah konsentrasi hasil pengukuran dan Lij adalah baku mutu yang harus dipenuhi dalam PP No. 82 Tahun 2001.

2. Prosedur perhitungan $(\mathrm{Ci} / \mathrm{Lij})$ berdasarkan beberapa kondisi parameter.

3. Menentukan nilai rata - rata dan nilai maksimum dari keseluruhan $\mathrm{Ci} / \mathrm{Lij}$ $\left((\mathrm{Ci} / \mathrm{Lij})_{\mathrm{R}}\right.$ dan $\left.(\mathrm{Ci} / \mathrm{Lij})_{\mathrm{M}}\right)$.

4. Menentukan harga $\mathrm{PI}_{\mathrm{j}}$ atau $\mathrm{IP}$ dengan persamaan :

$$
\begin{aligned}
& \mathrm{PIj}=\sqrt{\frac{\{\mathrm{Ci} / \mathrm{Li}\}_{M}^{2}\{\mathrm{Ci} / \mathrm{Li}\}_{R}^{2}}{2}} \\
& \text { Metode ini dapat langsung }
\end{aligned}
$$
menghubungkan tingkat ketercemaran dengan dapat atau tidaknya sungai dipakai untuk penggunaan tertentu dan dengan nilai parameter - parameter tertentu (BLH Provinsi Bengkulu, 2016).

\section{HASIL DAN PEMBAHASAN}

Berdasarkan hasil analisis laboratorium yang dilakukan di UPTD Laboratorium Dinas Lingkungan Hidup dan Kehutanan Provinsi Bengkulu dan Dinas Lingkungan Hidup Kota Bengkulu, didapatkan hasil analisa air Sungai Nelas seperti yang disampaikan pada tabel berikut. Ada beberapa parameter yang secara langsung diketahui melebihi baku 
mutu air Sungai kelas 1, seperti parameter DO (Dissolved Oxygen), BOD (Biochemical Oxygen Demand), COD (Chemical Oxygen Demand), $\mathrm{Cu}$ (Tembaga), Fecal Coli, dan Total Coli pada beberapa titik pantau.

\section{Hasil Perhitungan Status Mutu Air menggunakan Metode STORET dan Indeks Pencemaran (IP).}

Analisis kualitas air dilakukan untuk mengetahui kesesuaian air untuk peruntukan tertentu dengan membandingkan status mutu air sesuai kelas air. Berdasarkan hasil analisis kualitas air Sungai Nelas, kemudian dilanjutkan dengan perhitungan status mutu air Sungai Nelas dengan menggunakan Metode STORET dan Indeks Pencemaran (IP) yang disajikan dalam tabel 2. Berdasarkan data hasil perhitungan dengan menggunakan metode STORET yang menunjukkan bahwa dari tahun 2014 s.d 2017 terjadi peningkatan skor nilai hasil perhitungan metode STORET dari -41 terus meningkat hingga -61 yang menunjukkan bahwa status mutu air Sungai Nelas sudah "cemar berat". Hal ini juga ditunjukkan dengan hasil uji bakteri E. Coli yang terdeteksi dari titik hulu sampai ke hilir. Hasil uji bakteri E. Coli menunjukkan bahwa sebaran pencemar mikrobiologi yang dominan berasal dari limbah domestik ini sudah mendominasi pencemaran di Sungai Nelas dari hulu sampai ke hilir. Tingginya skor nilai pada metode STORET juga sebagai sumbangan dari hasil uji bakteri E. Coli yang mendominasi pada setiap titik sampling.

Tabel 1. Hasil Analisis Sampel Air Sungai Nelas

\begin{tabular}{|c|c|c|c|c|c|c|c|c|c|c|c|c|c|}
\hline \multirow{2}{*}{ No. } & \multirow{2}{*}{ Parameter } & \multirow{2}{*}{ Satuan } & \multirow{2}{*}{$\begin{array}{c}\text { Baku } \\
\text { Mutu** }\end{array}$} & \multicolumn{5}{|c|}{ Musim Kemarau } & \multicolumn{5}{|c|}{ Musim Penghujan } \\
\hline & & & & Hulu & Tengah 1 & Tengah 2 & Tengah 3 & Hilir & Hulu & Tengah 1 & Tengah 2 & Tengah 3 & Hilir \\
\hline \multicolumn{14}{|c|}{ FISIKA } \\
\hline 1 & Suhu air & $\mathrm{C}$ & Deviasi 3 & 28,7 & 29 & 29,8 & 29,3 & 28,7 & 26,6 & 26,7 & 29 & 27,2 & 31,1 \\
\hline 2 & TDS & $\mathrm{mg} / \mathrm{L}$ & 1000 & 15,53 & 15,59 & 16,02 & 15,73 & 30,8 & 20,34 & 18,78 & 19,53 & 18,65 & 38,7 \\
\hline 3 & DHL & $\mu \mathrm{s} / \mathrm{cm}$ & - & 33,2 & 33,4 & 34,2 & 33,3 & 67 & 43,3 & 40 & 41,8 & 40,1 & 83,1 \\
\hline 4 & $\mathrm{pH}$ & & $6-9$ & 6,54 & 6,65 & 6,62 & 6,48 & 6,84 & 6,14 & 6,11 & 6,14 & 6,58 & 6,81 \\
\hline 5 & TSS & $\mathrm{mg} / \mathrm{L}$ & 50 & 1 & 1 & 2 & 2 & 6 & 1 & 2 & 18 & 1 & 7 \\
\hline \multicolumn{14}{|c|}{ KIMIA } \\
\hline 1 & DO & $\mathrm{mg} / \mathrm{L}$ & 6 & $5,73 * *$ & 5,39 ** & 6,63 & $4,12 * *$ & $5,01 * *$ & $3 * *$ & 7,39 & $2,67 * *$ & $4,42^{* * *}$ & $5,77 * *$ \\
\hline 2 & $\mathrm{Fe}$ & $\mathrm{mg} / \mathrm{L}$ & 0,3 & 0,002 & 0,018 & 0,006 & 0,028 & 0,036 & 0,067 & 0,047 & 0,125 & 0,053 & 0,067 \\
\hline 3 & $\mathrm{Mn}$ & $\mathrm{mg} / \mathrm{L}$ & 0,1 & 0,028 & 0,029 & 0,032 & 0,05 & 0,065 & 0,007 & 0,004 & 0,045 & 0,007 & 0,021 \\
\hline 4 & $\mathrm{Cu}$ & $\mathrm{mg} / \mathrm{L}$ & 0,02 & 0,01 & 0,02 & 0,01 & 0,01 & 0,02 & $0,05^{* *}$ & $0,03 * *$ & 0,01 & 0,01 & $0,04 * *$ \\
\hline 5 & BOD5 & $\mathrm{mg} / \mathrm{L}$ & 2 & $5,3^{* *}$ & $5,7^{* *}$ & $14,6^{* *}$ & $8,6 * *$ & $2,6^{* *}$ & $2,8^{* *}$ & $6,4 * *$ & $3,4 * *$ & $3,6 * *$ & $2,9^{* *}$ \\
\hline 6 & COD & $\mathrm{mg} / \mathrm{L}$ & 10 & $16^{* *}$ & $17 * *$ & $44 * *$ & $26^{* *}$ & 8 & 9 & $19^{* *}$ & 10 & $11^{* *}$ & 10 \\
\hline 7 & SO4 & $\mathrm{mg} / \mathrm{L}$ & 400 & 1 & 1 & 1 & 4 & 1 & 32 & 11 & 8 & 2 & 2 \\
\hline 8 & Nitrit (NO2-N) & $\mathrm{mg} / \mathrm{L}$ & 0,06 & 0,002 & 0,002 & 0,027 & 0,003 & 0,004 & 0,001 & 0,001 & 0,032 & 0,001 & 0,001 \\
\hline 9 & Minyak dan lemak & $\mathrm{mg} / \mathrm{L}$ & 1000 & 283 & 131 & 126 & 156 & 211 & 0,722 & 0,06 & 0,028 & 0,082 & 0,042 \\
\hline 10 & Salinitas & $\%$ & - & 0,01 & 0,01 & 0,01 & 0,01 & 0,03 & 0,02 & 0,02 & 0,02 & 0,02 & 0,04 \\
\hline \multicolumn{14}{|c|}{ BIOLOGI } \\
\hline 1 & Total Coli & $\begin{array}{l}\mathrm{Jml} / 100 \\
\mathrm{ml} \\
\mathrm{Jml} / 100\end{array}$ & 1000 & 900 & 900 & 900 & $2500^{* *}$ & $3000^{* *}$ & 1000 & 900 & 900 & 900 & $1500^{* *}$ \\
\hline 2 & Coliform/Fecal Coli & & 100 & $400^{* *}$ & $500^{* *}$ & $600^{* *}$ & $700^{* *}$ & $800^{* *}$ & $400^{* *}$ & $500 * *$ & $600^{* * *}$ & $700^{* *}$ & $800 * *$ \\
\hline
\end{tabular}

Keterangan :

* = Baku Mutu air Sungai kelas I berdasarkan Perda Nomor 6 Tahun 2005 Tentang Penetapan Baku Mutu Air dan Kelas Air Sungai Lintas Kabupaten/Kota Dalam Provinsi Bengkulu.

**= Melebihi baku mutu air Sungai Kelas I yang telah ditetapkan berdasarkan Perda Nomor 6 Tahun 2005.

Tabel 2. Hasil perhitungan status mutu air Sungai Nelas

\begin{tabular}{ccccc}
\hline No & Sungai Nelas & $\begin{array}{c}\text { Skor } \\
\text { (STORET) }\end{array}$ & Status & Keterangan \\
\hline 1. & 2014 & -41 & Cemar berat & \\
2. & 2015 & -41 & Cemar berat & \\
3. 2016 & -57 & Cemar berat & \\
4. & 2017 & -61 & Cemar berat & \\
\hline
\end{tabular}


Secara umum, besarnya nilai Total Coli dan Fecal coli pada semua titik sampling tersebut menunjukkan besarnya jumlah limbah domestik yang masuk kedalam badan perairan. Menurut Suriawiria (1993) kehadiran mikroba patogen di dalam air akan meningkat jika jumlah kandungan bahan organik di dalam air cukup tinggi, yang berfungsi sebagai tempat dan sumber kehidupan mikroorganisme.

Tidak jauh berbeda dengan metode STORET, metode Indeks Pencemaran (IP) pun menunjukkan bahwa pada setiap titik sampling sudah mengalami pencemaran. Dari hasil uji dengan menggunakan Indeks Pencemaran (IP), menunjukkan bahwa pada setiap titik sampling dari hulu sampai ke hilir menunjukkan status "cemar ringan".

Hasil perhitungan status mutu air dengan metode Indeks Pencemaran (IP) menunjukkan bahwa, kualitas air Sungai Nelas dari titik hulu (Desa Talang Sebaris), titik tengah 1 (Kecamatan Periukan), titik tengah 2 (Kecamatan Sukaraja), titik tengah 3 (Desa Jenggalu), hingga ke titik hilir (Kelurahan Padang Serai) mengalami penurunan status mutu air, hal ini ditandai dengan semakin meningkatnya nilai Indeks Pencemaran (IP). Status mutu air pada lokasi pengamatan dari titik Hulu hingga ke lokasi pengamatan titik Hilir menunjukkan telah tercemar dengan status "cemar ringan". Nilai Indeks Pencemaran (IP) dari berasal dari sektor rumah tangga. Hal ini juga secara tidak langsung menunjukan bahwa perumahan masyarakat masih banyak yang tidak memiliki IPAL dan langsung menggunakan aliran air Sungai hulu hingga ke hilir cenderung mengalami peningkatan meskipun di beberapa lokasi pengamatan sampel air mengalami fluktuasi. Hal ini menunjukkan bahwa kondisi kualitas air Sungai Nelas sangat berkaitan dengan penggunaan lahan dan aktivitas masyarakat di sekitarnya. Menurut Tong \& Chen (2002), kondisi hidrologi suatu DAS sangat tergantung pada faktor penggunaan lahan, iklim dan kondisi tanah. Selanjutnya hubungan antara penggunaan lahan dan status kualitas air adalah kompleks dan cenderung spesifik lokasi, sehingga diperlukan kerja keras untuk mewujudkan jumlahnya yang benar - benar terukur (Tallar \& Suen, 2015).

\section{Evaluasi Status Mutu Air Sungai Nelas dari Tahun 2014 sampai Tahun 2017}

Tahun 2014 status Sungai Nelas dengan menggunakan metode STORET terus mengalami kenaikan skor nilai, dari 41 (cemar berat), -57 (cemar berat), hingga terakhir -61 (cemar berat). Hal tersebut menunjukkan bahwa semakin lama status cemaran didalam aliran Sungai Nelas semakin besar. Hal ini berkorelasi dengan pertumbuhan jumlah penduduk yang terus bertambah setiap tahunnya, sehingga sedikit banyak akan berpengaruh terhadap jumlah cemaran yang masuk kedalam aliran air Sungai Nelas. Hal tersebut juga ditunjukkan dengan data sumber pencemar dominan yang menunjukkan bahwa cemaran COD, BOD, dan TSS sebagai media mandi, cuci, dan kakus. Hal tersebut juga ditunjukkan dengan hasil uji bakteri E. Coli yang dominan melebihi baku mutu air Sungai Kelas 1 (Satu) disetiap lokasi titik sampling.

Tabel 3. Hasil perhitungan status mutu air Sungai Nelas

\begin{tabular}{|c|c|c|c|c|c|}
\hline No & Lokasi & \multicolumn{2}{|c|}{ Titik Koordinat } & Skor & Keterangan \\
\hline 1 & Hulu (Desa Talang Sebaris). & ${\mathrm{S} 03^{\circ} 55^{\prime} 12.5^{\prime \prime}}^{\prime}$ & $\mathrm{E} 102^{\circ} 28^{\prime} 28^{\prime \prime}$ & 4,304 & Cemar ringan \\
\hline 2 & Titik Tengah 1 (Desa Lubuk Payung). & S $03^{\circ} 55^{\prime} 22.57^{\prime \prime}$ & E $102^{\circ} 26^{\prime} 10.03^{\prime \prime}$ & 4,966 & Cemar ringan \\
\hline 3 & Titik Tengah 2 (Kecamatan Sukaraja). & S $03^{\circ} 55.9^{\prime} 33^{\prime \prime}$ & E $102^{\circ} 24,9^{\prime} 28^{\prime \prime}$ & 4,319 & Cemar ringan \\
\hline 4 & Titik Tengah 3 (Desa Jenggalu). & $\mathrm{S} 03^{\circ} 55^{\prime} 03.48^{\prime \prime}$ & E $102^{\circ} 21^{\prime} 56.5^{\prime \prime}$ & 4,296 & Cemar ringan \\
\hline 5 & Hilir (Kelurahan Padang Serai). & S $03^{\circ} 54^{\prime} 60.4^{\prime \prime}$ & E $102^{\circ} 19.1^{\prime} 31^{\prime \prime}$ & 4,302 & Cemar ringan \\
\hline
\end{tabular}


Tidak berbeda jauh dengan menggunakan metode Indeks Pencemaran (IP), hal serupa ditunjukkan dengan nilai skor yang diberikan dengan rata - rata status cemar ringan. Pada setiap titik pantau dari hulu sampai ke hilir menunjukkan status cemar ringan. Hal tersebut juga menunjukkan kenaikan nilai skor perhitungan dengan menggunakan metode Indeks Pencemaran (IP). Kenaikan skor nilai berkorelasi dengan kenaikan nilai parameter pencemar pada setiap titik pantau dan hal tersebut berkorelasi dengan pertambahan jumlah penduduk yang ditunjukkan juga dengan sumber pencemar dominan dari sektor rumah tangga yang dominan menyumbangkan parameter COD, BOD, dan TSS.

Hal tersebut juga didukung kuat oleh data pertambahan jumlah penduduk dari tahun ke tahun yang sedikit banyak berkontribusi terhadap jumlah limbah domestik yang masuk kedalam aliran Sungai Nelas, sehingga berpengaruh terhadap kadar parameter yang berhubungan langsung dengan limbah domestik, seperti parameter COD, BOD, E. Coli, dan parameter pencemar lainnnya.

Tabel 4. Evaluasi Status Mutu Sungai Nelas dari tahun 2014 s.d tahun 2017

\begin{tabular}{|c|c|c|c|c|}
\hline \multirow{2}{*}{ No } & Sungai Nelas & \multirow{2}{*}{$\begin{array}{c}\text { Skor } \\
\text { (STORET) }\end{array}$} & \multirow{2}{*}{ Status } & \multirow{2}{*}{ Keterangan } \\
\hline & Tahun & & & \\
\hline 1. & 2014 & -41 & Cemar berat & \\
\hline 2. & 2015 & -41 & Cemar berat & \\
\hline 3. & 2016 & -57 & Cemar berat & \\
\hline 4. & 2017 & -61 & Cemar berat & \\
\hline
\end{tabular}

Tabel 5. Evaluasi Status Mutu Sungai Nelas dari tahun 2014 s.d tahun 2017

\begin{tabular}{|c|c|c|c|c|}
\hline No & $\begin{array}{c}\text { Sungai Nelas } \\
\text { Tahun }\end{array}$ & $\begin{array}{l}\text { Skor } \\
\text { ( IP ) }\end{array}$ & Status & Keterangan \\
\hline 1. & 2014 & 3,43 & Cemar ringan & \\
\hline 2. & 2015 & 3,39 & Cemar ringan & \\
\hline 3. & 2016 & 2,40 & Cemar ringan & \\
\hline 4. & 2017 & 4,43 & Cemar ringan & \\
\hline
\end{tabular}

Tabel 6. Data Pertambahan Jumlah Penduduk disepanjang DAS Nelas

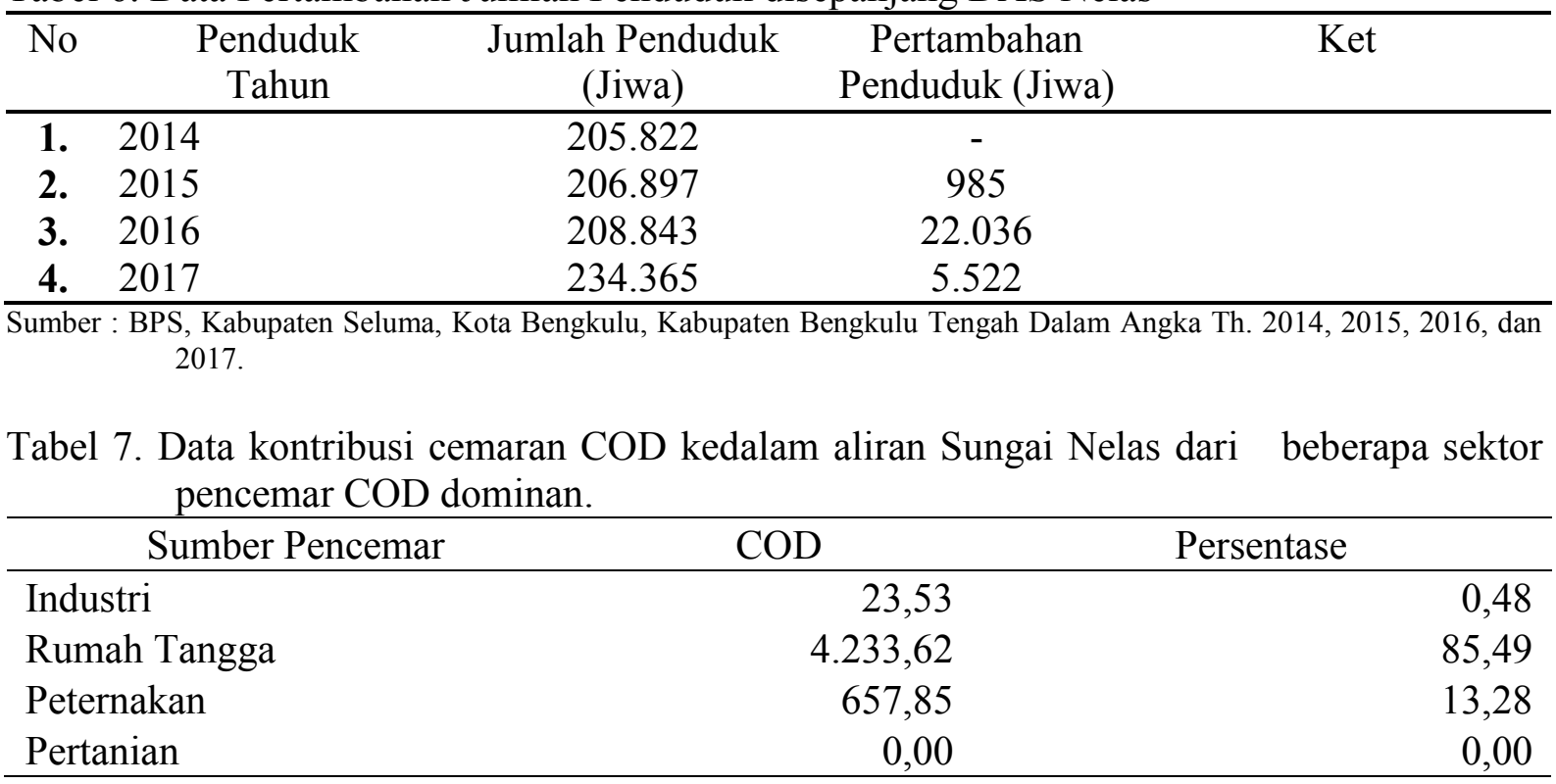




\begin{tabular}{lrr}
\hline Perikanan & 8,04 & 0,16 \\
Sampah & 28,98 & 0,59 \\
\hline Total & $4.952,02$ & 100,00 \\
\hline
\end{tabular}

Berdasarkan data pertumbuhan jumlah penduduk setiap tahun yang menunjukkan angka $>900$ jiwa per tahun, berkorelasi berbanding lurus dengan hasil analisa data metode STORET dan Indeks Pencemaran (IP) yang menunjukkan tingkat pencemaran di Sungai Nelas yang didominasi oleh limbah domestik rumah tangga, dan ini ditunjukkan oleh hasil perhitungan analisa beban pencemar dominan dari beberapa sektor yang menunjukkan parameter BOD, COD, TSS, dan E. Coli yang dominan berasal dari sektor rumah tangga (limbah domestik).

\section{Analisis Sumber Pencemar}

Berdasarkan data tersebut didapatkan kontribusi sumber pencemar COD berasal beberapa sektor seperti industri, rumah tangga, peternakan, pertanian, perikanan, dan sampah. Sektor penyumbang pencemar COD terbesar ke aliran Sungai Nelas berasal dari sektor rumah tangga sebesar 4.233,62 Kg/hari (86\%) kedalam aliran Sungai Nelas. Kemudian penyumbang COD terbesar kedua berasal dari sektor Peternakan sebesar $657,85 \mathrm{Kg} /$ hari (13\%), kemudian penyumbang COD terbesar ketiga dari sektor sampah sebesar 28,98 $\mathrm{Kg}$ /hari $(0,59 \%)$, kemudian berikutnya disumbangkan dari sektor industri sebesar $23,53 \mathrm{Kg} /$ hari $(0,48 \%)$, kemudian dari sektor perikanan sebesar $8,04 \mathrm{Kg} /$ hari $(0,16 \%)$, dan terakhir dari sektor pertanian tidak ada menyumbangkan COD ke aliran Sungai Nelas $(0 \%)$.

\section{KESIMPULAN}

1. Kualitas air Sungai Nelas pada Kelima titik sampling dari bagian hulu (Desa Talang Sebaris, Kecamatan Periukan Kab. Seluma), titik tengah 1 (Desa Lubuk Payung Kabupaten Seluma), titik tengah 2 (Kecamatan Sukaraja Kabupaten Seluma), titik tengah 3 (Desa Jenggalu Kabupaten Seluma), dan hilir (Kelurahan Padang Serai Kecamatan Kampung Melayu Kota Bengkulu) sudah mengalami penurunan kualitas, dengan status "cemar ringan" (berdasarkan metode Indeks Pencemaran), dan "cemar berat" (berdasarkan metode STORET).

2. Dengan adanya penurunan kualitas air Sungai Nelas dengan status "cemar ringan" (berdasarkan metode Indeks Pencemaran), dan "cemar berat" (berdasarkan metode STORET), maka peruntukan air Sungai Nelas tidak layak lagi untuk air baku air minum berdasarkan Peraturan Daerah nomor 6 tahun 2005 yang mengatur Sungai Nelas sebagai air Sungai kelas 1 (Satu) dan berdasarkan Peraturan Menteri Kesehatan nomor 492 tahun 2010 tentang Persyaratan kualitas air minum, tetapi masih layak peruntukannya untuk digunakan sebagai prasarana/sarana rekreasi air, pembudidayaan ikan air tawar, peternakan, air untuk mengairi pertanaman.

3. Dengan hasil uji yang menunjukkan adanya penurunan kualitas air Sungai Nelas dari hulu hingga ke hilir dengan status "cemar ringan" (berdasarkan metode Indeks Pencemaran), dan "cemar berat" (berdasarkan metode STORET) maka status Sungai Nelas tidak layak lagi ditetapkan sebagai air Sungai kelas 1 (Satu) seperti yang tercantum didalam Peraturan Daerah No. 6 tahun 2005 tentang Penetapan Baku Mutu Air dan Kelas Air Sungai Lintas Kabupaten/ Kota dalam Propinsi Bengkulu. 
4. Kualitas air Sungai Nelas dari tahun 2014 sampai tahun 2017 sudah menunjukkan penurunan status mutu air, sehingga tidak bisa lagi dimanfaatkan sesuai peruntukan air kelas I (Satu) yaitu untuk air baku air minum dan peruntukan lain yang

\section{DAFTAR PUSTAKA}

BPS Kabupaten Seluma. 2014. Kabupaten

Seluma Dalam Angka 2014.

Error! Hyperlink reference not valid.

BPS Kabupaten Seluma. 2015. Kabupaten

Seluma Dalam Angka 2015.

Error! Hyperlink reference not valid.

BPS Kabupaten Seluma. 2016. Kabupaten

Seluma Dalam Angka 2016.

Error! Hyperlink reference not valid.

BPS Kabupaten Seluma. 2017. Kabupaten

Seluma Dalam Angka 2017.

Error! Hyperlink reference not valid.

Eko Budiharjo. 2015. Kota dan Lingkungan, Pendekatan Baru Masyarakat Berwawasan Lingkungan Ekologi.

Endang S, Alikodra, Hariadi K, Roemantyo, Setiawan P. 2017. Pengelolaan Kawasan Ekosistem Esential dalam Rangka Memperkuat Revisi UU No. 5/1990. Kementerian Lingkungan Hidup dan Kehutanan. White Paper.

Hadi, A. 2005. Prinsip pengelolaan pengambilan sample lingkungan, PT. Gramedia Pustaka Utama, Jakarta. mempersyaratkan mutu air yang sama dengan kegunaan tersebut, sehingga diperlukan upaya pengelolaan air Sungai Nelas, agar dapat tetap bermanfaat bagi kehidupan masyarakat di Provinsi Bengkulu.

Hendryo N. 2015. Hutan Penyangga Lingkungan Hidup dan Daya Saing Negara. Penerbit Gosyen.

Imam Santoso. 2015. Kesehatan Lingkungan Permukiman Perkotaan. Penerbit Gosyen.

Karliansyah, 2016. Atlas Status Mutu Air Indonesia. Direktur Jenderal Pengendalian Pencemaran dan Kerusakan Lingkungan. KLHK RI.

Keputusan Menteri Negara Lingkungan Hidup Nomor 115 Tahun 2003. Pedoman Penentuan Status Mutu Air. KLHK RI.

Mallongi, A. 2015. Dampak Limbah Cair dari Aktivitas Institusi dan Industri. Penerbit Gosyen. Cetakan Pertama.

Manik K.E.S. 2016. Pengelolaan Lingkungan Hidup Edisi Pertama. Perpustakaan Nasional : Katalog Dalam terbitan (KDT). Prenadamedia Group.

Mundiatun, Daryanto. 2016. Pengelolaan Kesehatan Lingkungan. Penerbit Gava Media.

Nyoman Wijana. 2014. Ilmu Lingkungan Edisi 2. Penerbit Graha Ilmu. Cetakan Kedua. 2014

Pardamean Sebayang. 2015. Teknologi Pengolahan Air Kotor dan Payau Menjadi Air Bersih dan Layak Minum. Lembaga Ilmu Pengetahuan Indonesia (LIPI).

Peraturan Daerah Provinsi Bengkulu Nomor 6 Tahun 2005. Penetapan Baku Mutu Air dan Kelas Air Sungai 
Lintas Kabupaten / Kota dalam Provinsi Bengkulu.

Peraturan Pemerintah Nomor 38 Tahun 2011. Sungai.

Peraturan Pemerintah Nomor 82 Tahun 2001 tentang Pengelolaan Kualitas Air dan Pengendalian Pencemaran Air.

Rosalia A. 2017. Penentuan Status Mutu Air Sungai Kalimas dengan Metode STORET dan Indeks Pencemaran. Tesis. Institut Teknologi Sepuluh November. Surabaya. 2017

Saraswati,S.P., Sunyoto, Kironoto, B.A. dan Hadisusanto, S dalam Rosalia. 2014. Kajian Bentuk dan Sensitivitas Rumus Indeks Pencemaran, STORET, CCME untuk Penentuan Status Mutu Perairan Sungai Tropis di Indonesia. Jurnal Manusia dan Lingkungan, 21(2) p: 129-142.

SNI 6989.57 : 2008. Metoda Pengambilan Contoh Air Permukaan.

Suriawiria, Unus. 2003. Air dalam Kehidupan dan Lingkungan yang Sehat. Penerbit Alumni. Bandung. 2
Syukri Hamzah. 2013. Pendidikan Lingkungan, Sekelumit Wawasan Pengantar. Penerbit PT. Refika Aditama. Cetakan Kesatu.

Tafangenyasha, C. and T. Dzinomwa dalam Dyah Agustiningsih. 2005. Land-use Impacts on River Water Quality in Lowveld Sand River Systems in South-East Zimbabwe. Land Use and Water Resources Research 5 : 3.1-3.10. http://www.luwrr.com

Terno, D., Sembel. 2015. Toksikologi Lingkungan, Dampak Pencemaran dari Berbagai Bahan Kimia dalam Kehidupan Sehari - hari. Penerbit Andi.

Tresna Sastrawijaya. 2009. Pencemaran Lingkungan. Penerbit PT. Rineka Cipta. Wiwoho, 2005, Model Identifikasi Daya Tampung Beban Cemaran Sungai Dengan QUAL2K. Tesis. Universitas Diponegoro. Semarang. 